\title{
From Virtue to Power: Explorations in Female Heroism - The Mosaics of Lilian Broca
}

\author{
Erdem'den Güce: Kadın Kahramanlığg Hakkında Keşifler - Lilian \\ Broca Mozaikleri
}

Angela CLARKE*

(Received 01 May 2020, accepted after revision 17 August 2020)

\begin{abstract}
This article examines the mosaics of the contemporary artist Lilian Broca. Broca has completed two monumental mosaic series, with another underway, on the biblical figures of: Esther, Judith, and Mary Magdelene. Through mosaic Broca explores women and their relationship to power in the ancient world. Broca notes that throughout ancient history the worth of women has been evaluated through the lense of beauty and chastity. Broca researched ancient text extensively to uncover examples of women who were atypical of this paradigm: women who spoke truth to power and transgressed the accepted boundaries. Her work illuminates the manner in which these women navigated, and even exploited the loopholes in ancient society, enabling them to exert their influence on the masculine domains of power.

Broca utilizes the medium of mosaic, since traditionally, it was a medium patronized by the most wealthy and privileged of ancient society. They were the sector of society who determined which stories would be most broadly disseminated and ultimately survive. Broca's work is postmodern employing both the concepts of temporality and axiology. For Broca, time and history are fluid. By utilizing the predominately masculine medium of mosaic to tell feminst stories she strives to resolve history's sins of omissions and the general absence of the female perspective in ancient history.

Finally, Broca notes that the media and placement of ancient monumental art has done much to elevate the stories of male heros above women. In this regard, she reflects Paul Veyne's concept of axiology, a term which enables social historians to evaluate the fluctuating value of social trends and historic objects. Broca suggests that by inserting a female narrative into ancient monumental art forms such as mosaic the stories of ancient women will finally be accorded with the same dignity and respect as their male counter parts.
\end{abstract}

Keywords: Mosaic, Mary Magdelene, Judith, Lilian Broca, ancient women.

Öz

Bu makale, çăgdaş sanatçı Lilian Broca'nın mozaiklerini incelemektedir. Broca, İncil'deki figürlerden Esther, Judith ve Magdalalı Meryem olmak üzere iki anttsal mozaik serisini tamamlad. Mozaik sayesinde Broca kadınları ve kadınların antik dünyadaki iktidarla ilişskilerini araştırmaktadır. Broca, kadınların değerinin antik tarih boyunca güzellik ve iffet merceğiyle değerlendirildiğini belirtir. Broca, bu paradigmadan atipik olan kadınların yani iktidara gerçekleri söyleyen ve kabul edilen sınırları aşan kadınların örneklerini ortaya çıkarmak için eski metinleri kapsamlı bir şekilde araştırmıştır. Eserleri, bu kadınların seyir tarzını aydınlatmakta ve hatta antik toplumdaki boşlukları kullanarak erkeksi güç alanları üzerindeki etkilerini göstermektedir.

\footnotetext{
* Angela Clarke, PhD, Italian Cultural Centre Museum, 3075 Slocan Street, Vancouver, BCV5M 3E4, Canada.
} 5374. E-mail: angelac@iccvancouver.ca 
Broca mozaik sanatını kullanır, çünkü mozaik geleneksel olarak antik toplumun en zengin ve ayrıcalıklı kesiminin himayesinde olan bir ortamdır. Mozaik hangi hikâyelerin en yaygın şekilde yayılacağını ve nihayetinde hayatta kalacağını belirleyen bir toplum sektörüdür. Broca'nın eserleri hem geçicilik hem de aksiyoloji kavramlarını kullanan postmodern eserlerdir. Broca için zaman ve tarih akıcıdır. Feminist hikâyeleri anlatmak için ağırlıklı olarak erkeksi mozaik ortamını kullanarak, tarihin ihmalkârlık günahlarını ve antik tarihte kadın bakış açısının genel yokluğunu çözmeye çalışır.

Nihayetinde, Broca, antik anıtsal sanatın ortamının ve yerleşiminin erkek kahramanların hikâyelerinin kadınların hikâyelerinden daha yükseğe yerleştirmek için çok şey yaptığına dikkat çekmektedir. Bu bağlamda, Paul Veyne'nin sosyal tarihçilerin sosyal eğilimlerin ve tarihi nesnelerin dalgalanan değerlerini değerlendirmesini sağlayan bir terim olan aksiyoloji kavramını yansitmaktadır. Broca, mozaik gibi eski anıtsal sanat formlarına bir kadın anlatı ekleyerek, antik kadınların hikâyelerinin nihayet erkek karşıtlarının hikâyeleri ile aynı onur ve sayg ile tanınacă̆ını ileri sürmektedir.

Anahtar Kelimeler: Mozaik, Magdalalı Meryem, Judith, Lilian Broca, antik kadınlar.

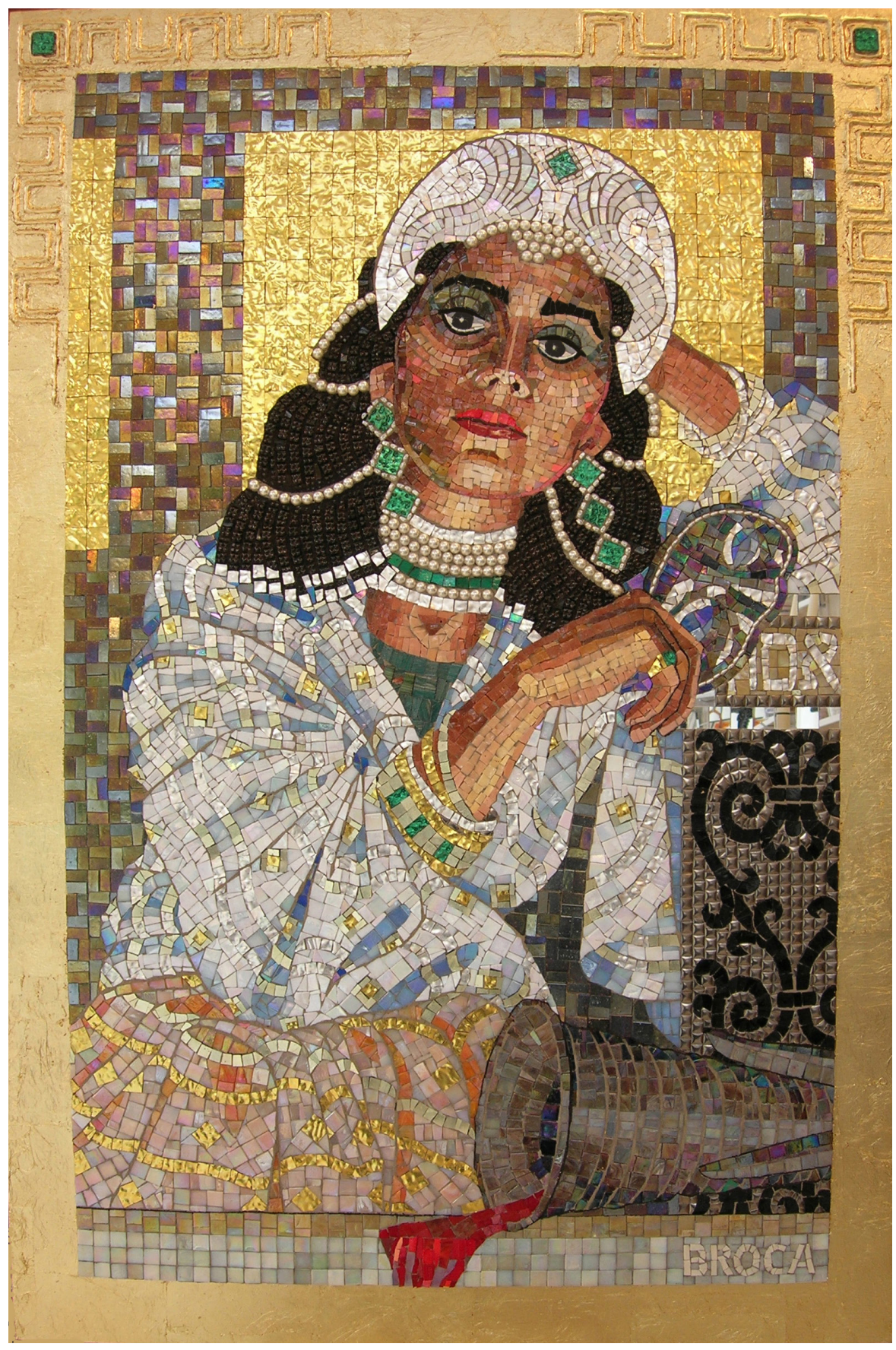

Figure 1

Queen Esther Revealing her True Identity, 48 " x 33" Iridium smalti, gems, gold tessera, gold leaf on panel, 2006. 

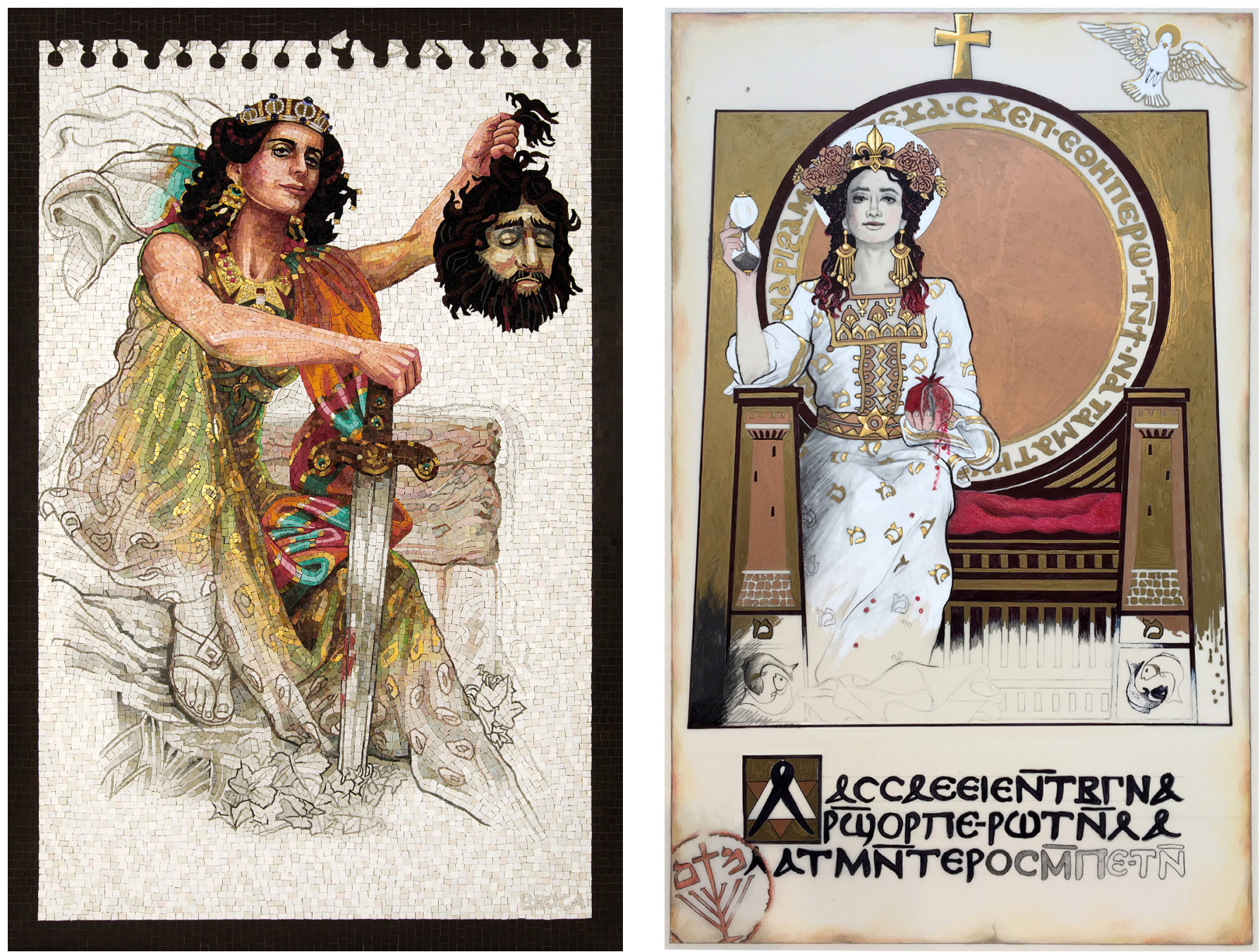

Figure 2

Judith Displaying Her Trophy, 73.5 " x 48" or 187 x $122 \mathrm{~cm}$ Byzantine Smalti, Millefiori, Gold smalti, Ceramic tiles on Border. Honeycomb panel, 2014.

Figure 3

Painted Cartoon for Mary Magdalene Awaiting Emmanuel, 79" x 48" or $200 \mathrm{x}$ $122 \mathrm{~cm}$, Byzantine Smalti, gold tesserae on honeycomb panel (mosaic in progress).
For Lilian Broca, the mosaic genre is the perfect pairing of medium and message.

Throughout her artistic career, Broca has explored disparities in masculine and feminine power dynamics as rendered over the history of art. For Broca this discrepancy is most exemplified in the ancient medium of mosaic. For this reason, she has researched and utilized this artistic genre in the second half of her career, leaving figurative painting and drawing behind. In Broca's estimation, mosaic has served over its long history to document masculine achievement. In contrast, depictions of women are restricted to the realm of saintly figures, mythological deities or mono-dimensional allegorical figures who embody specific feminine virtues or esoteric concepts.

Broca's work uses the ancient form of mosaic in a postmodern manner, bridging time and history to insert the female experience into the masculine domain. For Broca, contemporary mosaic is the perfect forum for exploring women who speak truth to power. Broca's vision is to re-examine how women exerted influence in society, politics and the religious realm within antiquity. Relying on ancient texts to inform her artistic work, she searches and brings to light ancient female heroes who embody not only power but auctoritas. This ancient Latin word for extraordinary personal authority has historically only been ascribed to male heroes. Broca asks why the court of history has commodified and measured women's social worth solely by virtue and beauty. She seeks to redress history's 
sins of omission by bringing to light stories of women from antiquity whose lives and social worth were not simply evaluated through the limiting qualities of pudor (Cic. Cael.: 38, 42, 49) ${ }^{1}$.

Offering her theories about ancient women and power through mosaics, Broca employs three women whose tales are recounted in ancient texts: Esther from the Bible, Judith from the Apocrypha and Mary Magdalene from both the Biblical and Gnostic traditions. In depicting these women in mosaic form, she demonstrates that issues pertaining to women and power in the ancient world were complex. Despite the obvious limitations inherent in the feminine sphere, they found ways to wield significant influence outside the traditional maledominated socioeconomic institutions of landowning, politics and the military. Through painstaking arrangement of thousands of Venetian glass fragments, Broca offers her narrative.

Mosaic as Masculine Achievement and Female Allegory
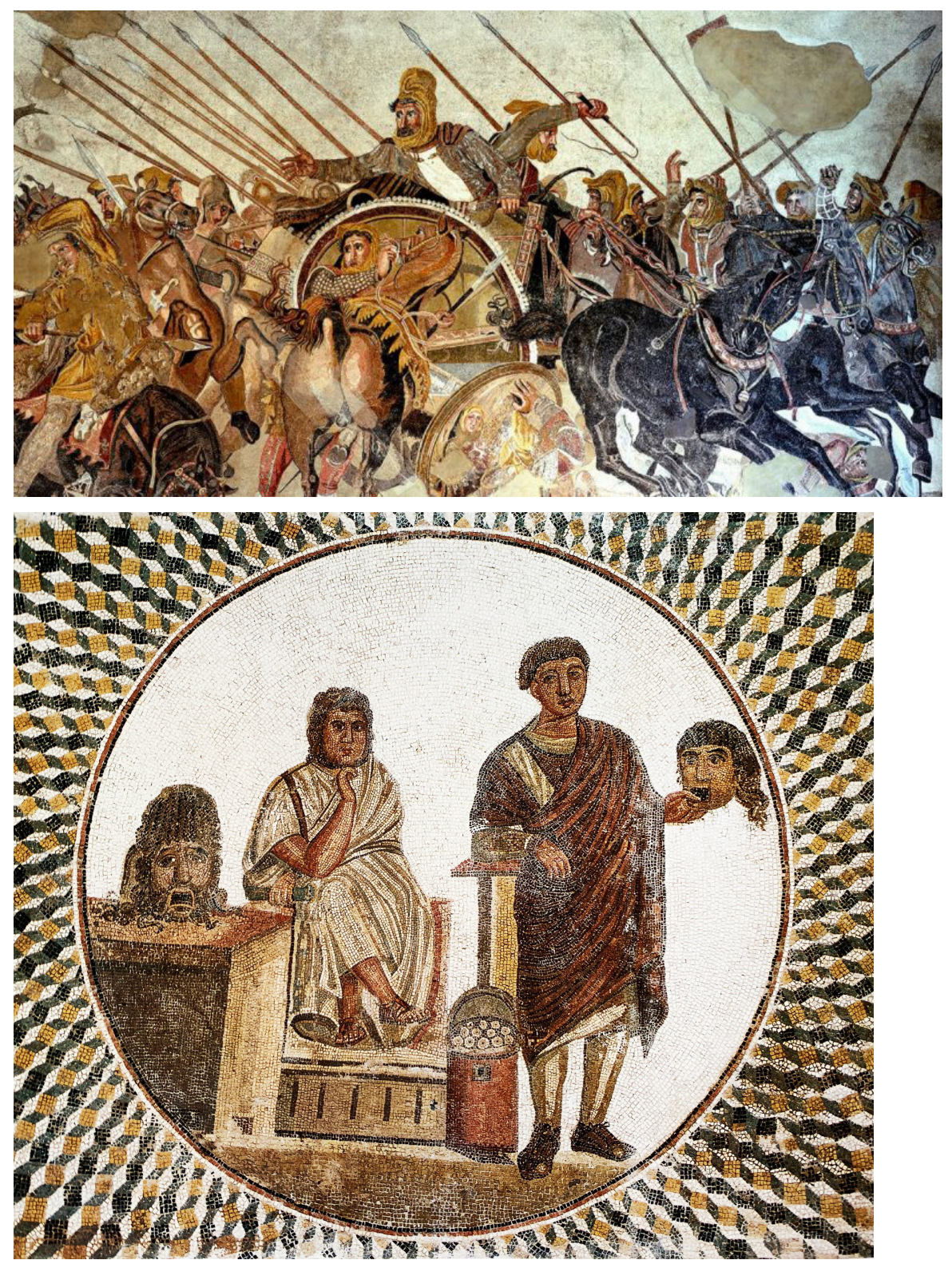

1 For the best description of pudor and pudicitia, see Cic. Cael.: 38, 42, 49. Clodia is viewed as the antithesis of this feminine behaviour. Cicero also contrasts pudor, largely described as a feminine virtue, with virtus, the masculine equivalent.
Figure 4

Alexander the Great Battle at Issus.

Figure 5

Actor and Poet Roman $3^{\text {rd }} \mathrm{c}$. 
Figure 6

Ancient Boxers Getty Villa, LA.
Figure 7

Athena Nabeul Museum Roman $4^{\text {th }} \mathrm{c}$.

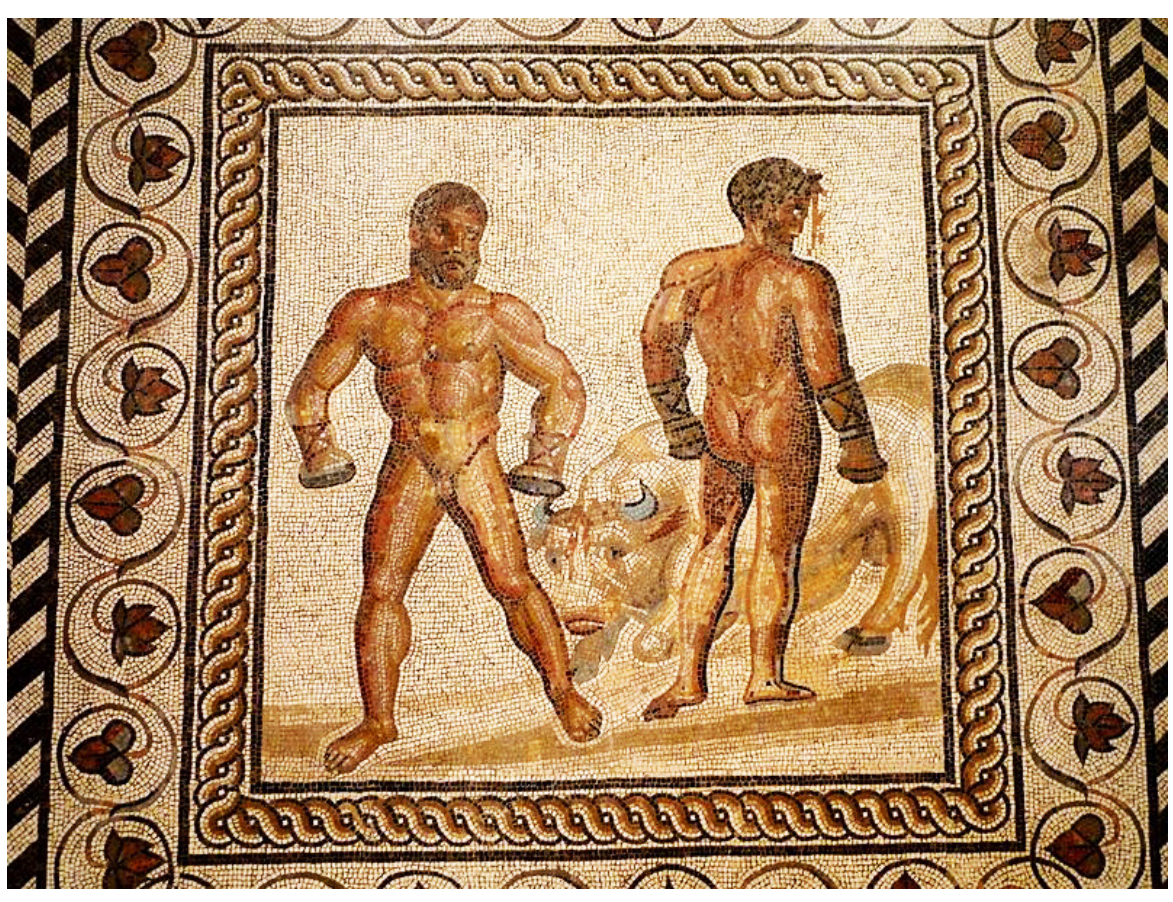

For Broca, ancient mosaic is as much a visual document of masculine achievement as an art form on a monumental scale offering insightful glimpses into daily life in the ancient world. While the mosaic of Alexander the Great's military campaign is the most invoked, there are other equally important socialhistorical scenes, such as male actors preparing for a tragic scene on stage at Pompeii. In addition, we see mosaics detailing Hercules and his many labours as well as athletes (wrestlers, boxers and runners) competing. Hence mosaic offers the full spectrum of masculine effort and political and social influences (Cohen 2010: 161) $)^{2}$.

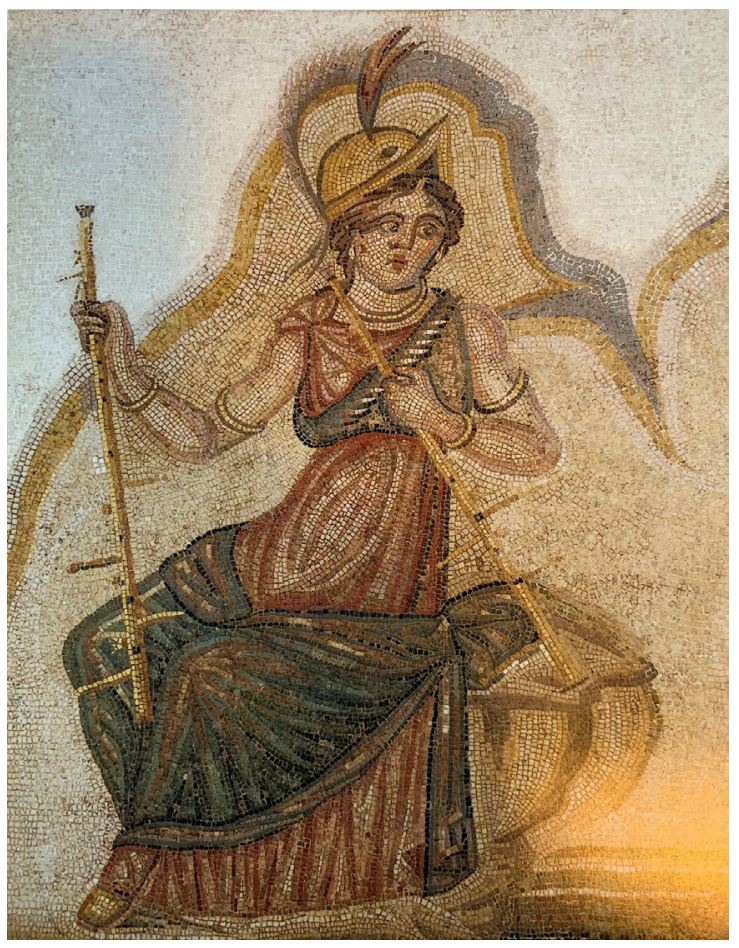

2 Cohen (2010: 161) brings up the notion that hunting and the rape of women in mosaic provide two parallels of masculine behaviour. This notion of rape and hunting provides context for the Judith story discussed later. 


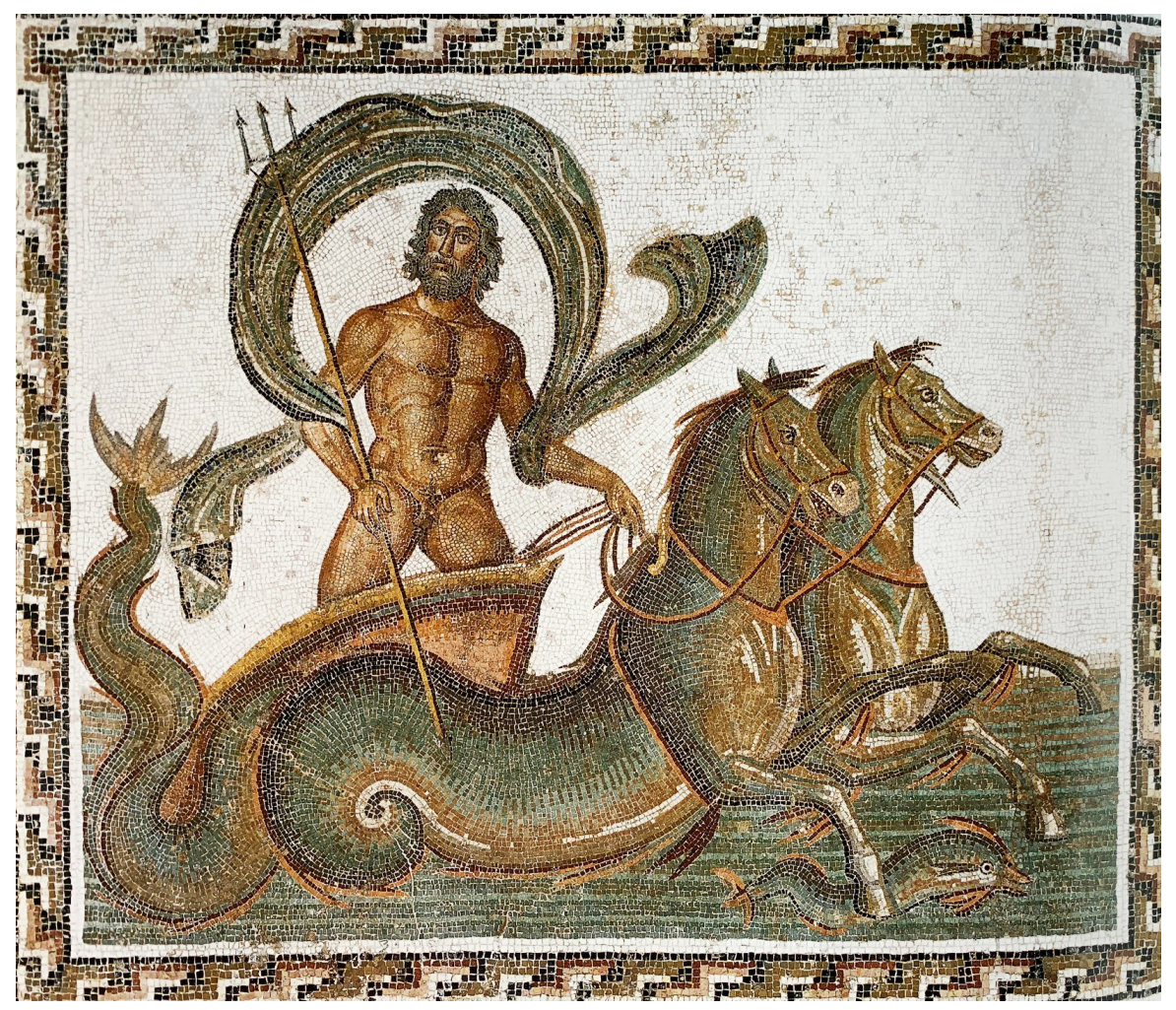

Figures 8

Neptune $4^{\text {th }}$ c. Sousse Museum.

However, female figures depicted in ancient mosaic are remote from lived experience. Women in mosaics, notes Broca, are relegated to unrelatable realms. They are goddesses outside the earthly sphere; or deities who personify abstraction, such as the seasons, justice or the feminine virtues of chastity and fertility in marriage. Influential texts such as Plutarch's Praecepta Conjugalis (first century BC) gave authority to and supported this notion of women (Plut. mor. Conj. Prae.1). In both his Moralia and his better-known Lives, Plutarch contributed to the prevailing concept in antiquity that these were innate masculine and feminine domains and gender-based behaviours (Warren 2018: 1). Plutarch, who wrote extensively on both masculine and feminine arete (excellence), noted in Moralia that while women possessed the capacity for arete as much as men, their means of doing so differed vastly. For men, arete meant duty and bravery; for women, it revolved entirely around service to their husbands and fathers (Warren 2018: 1). Plutarch clearly stated that wives should not overshadow their husbands and that they should be confined to the sphere of the household away from the public world. He even invoked the antique Egyptian model, which encouraged a husband to take away all adornments from his wife (gold, jewels and more expensive clothing), relieving her of incentive to leave the domestic sphere (Plut.mor. Conj. Prae.12).

Plutarch's text not only influenced Classical thought but remained significant with the advent of Christianity. The Christian tradition retained Plutarch's notions and superimposed onto them the ideals advocated through the textual genre of saintly hagiography. This new brand of religious literature ushered in a tradition of young virginal saints offered up as venerable and imitable examples of appropriate behaviour for girls and women. These women, whose stories were startlingly similar in tone and message, imparted a rigorous moral discipline reminding young readers to keep their eyes on the next world and spurn all pleasures offered up in this one (Wood 1996: 25; Clarke 2007: 142). The moral models promoted by hagiographic literature were a significant means through 
Figure 9

Bikini girls Villa del Casale Piazza Armerina, Sicily. which Church fathers such as Giovanni Domenici (1980: 145-146) and Jacobus de Voragine (1969) could shape the values of girls right from birth. As Domenici (1980: 144-145) noted, surrounding young girls in early childhood with the appropriate demarcations and examples of virtue would ensure that, by the time they matured into women, they would be so intimately acquainted with the feminine and domestic virtues that making the appropriate moral choices would be natural and innate. As Boccaccio noted in the $14^{\text {th }}$ century, this was essential since the ultimate objective was for girls to become virtuous and chaste wives, bringing honour to husband and family through their purity (Boccaccio 2001: $181)^{3}$. Therefore, when directed toward the female experience, mosaic worked with ideals, both idealizing beauty and allegorizing conduct.

Some rare examples of mosaics depict females engaged in active life. These include the $4^{\text {th }} \mathrm{c}$. Roman mosaic from Piazza Armerina in Sicily, which shows the "Bikini Girls" from the Coronation of the Winner, located in what is believed to have been the pleasure palace of Tetrarch Emperor Maximian. This mosaic depicts what was considered a women's only athletic contest featuring uninhibited females tossing a ball, throwing weights and the discus while wearing bikini briefs and a bandeau. However, this scene also features an allegorical persona. There is a yellow goddess, a figure in a toga who crowns the winners in victory (Doming 2012: 3) .

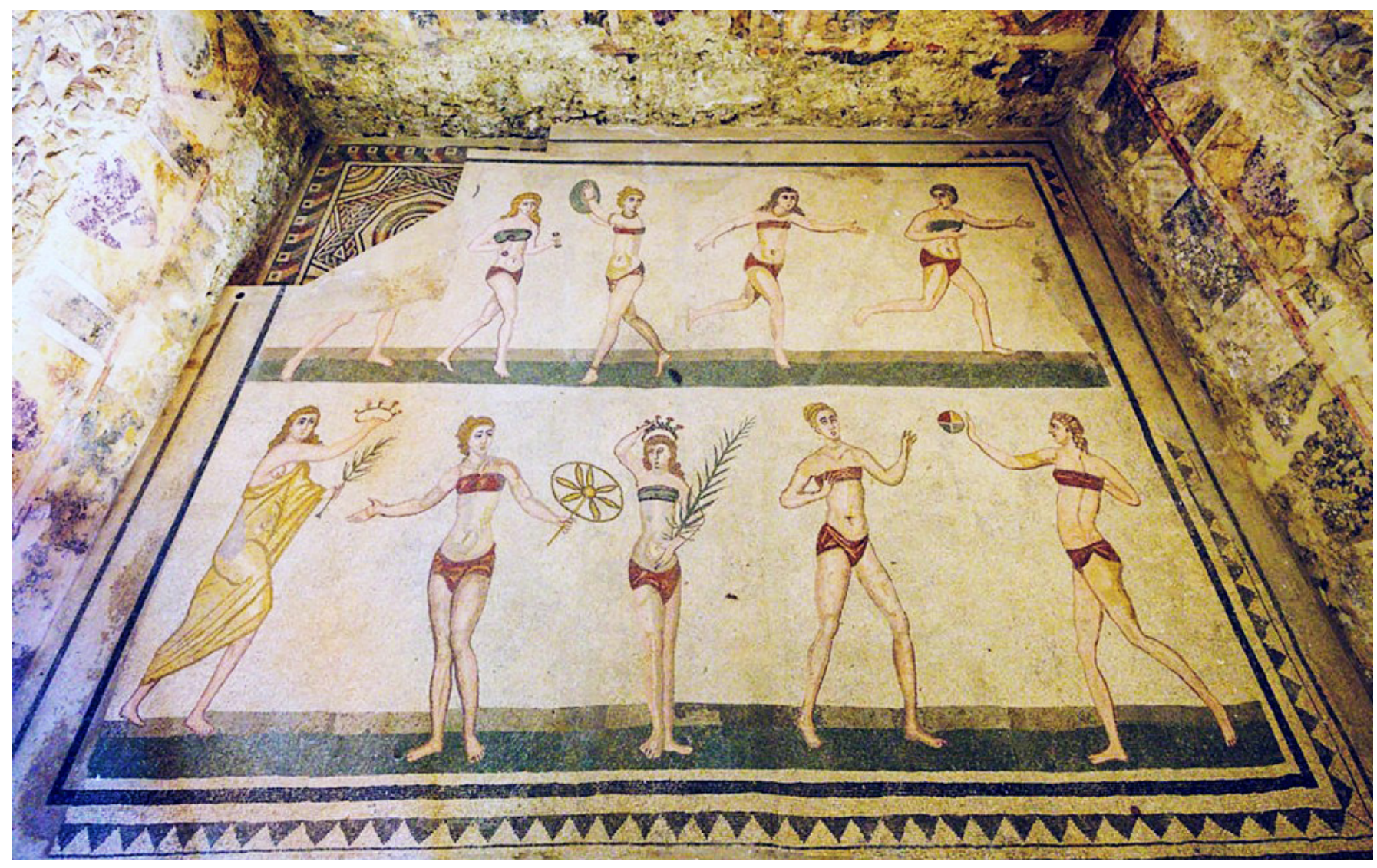

3 Boccaccio declared that chastity and devotion to ones husband should remain and continue throughout widowhood.

4 I suggest that this is not a goddess but one of the galli, eunuch priests of Cybele. 


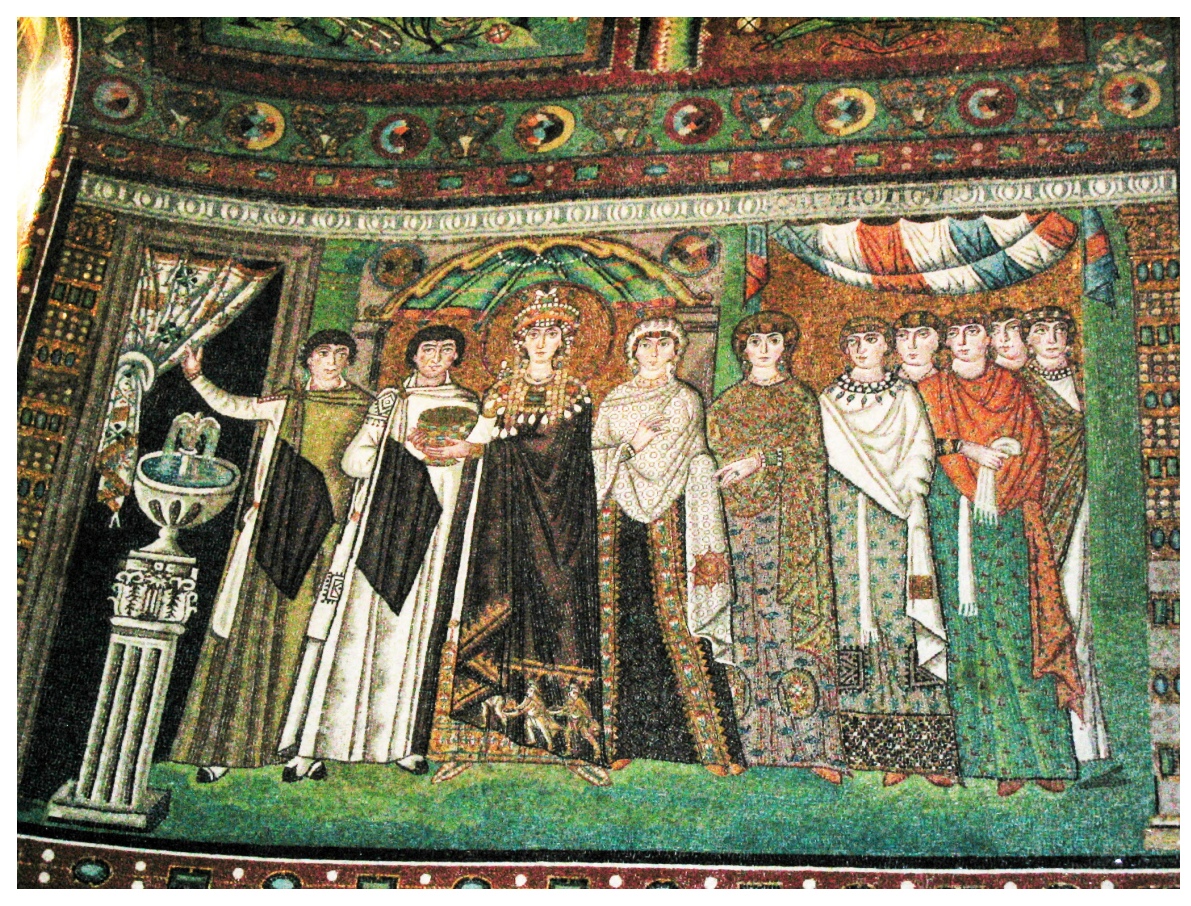

Another famous mosaic that departs from the formula of goddesses and allegories is the mosaic of Empress Theodora at the Church of San Vitale in Ravenna. Here Theodora is not cast in the guise of an allegory or a saint; rather, she is endowed with the powers of a consort or partner who exercises power through her husband Justinian. She is, however, not a leader in her own right. In this respect this work still references Plutarch's notion that a woman must be in service to her husband (Plut.mor.; Warren 2018: 2).

The above two examples are unusual since the genre of ancient mosaic rarely depicts women actively engaging in life or participating independently in the public realm. Instead, female figures in mosaic embody or personify feminine virtues. Women are not memorialized for their tangible contributions to history or society, nor for their navigation of complex emotions or for their political astuteness. Historically, as Broca has noted, mosaic imparts an element of unreality in its renderings of women, as if women existed only in the realm of the ethereal. Mosaic offers a selective vision that erases their possible participation in daily life outside the domestic sphere. Women are not seen to tread, let alone engage in, the halls of power, where influence in politics, the military and economics is exerted.

Thus Broca, by rendering in mosaic three legendary female figures, demonstrates that ancient texts offer examples of women who exerted power in the political, military and economic realms and that this power was not merely relegated to the service of fathers and husbands. Broca inserts this vision of female authority into the mosaic form, the very medium that historically denied such a possibility. However, Broca (January 5, 2015) is quick to assert that given the limitations on women's roles, they took indirect routes into the traditional channels of authority. Yet despite obvious restrictions, their capacity to affect social change remained significant and was deeply felt in the political, economic and military world of antiquity.

Broca uses both text and mosaic to depict three women: Esther, who defied the laws of her husband; Judith, who defied the will of the elders of her town; and finally Mary Magdalene, whose powerful role, especially in its relationship
Figures 10

Empress Theodora, San Vitale Church, Ravenna. 
Figure 11

Queen Esther, 75" x 33", Venetian glass, gold tessera, gems, gold leaf on wood panel, 2002.

Figure 12

Judith's Revenge, 70.5 " x 48 " or $179 \mathrm{x}$ $122 \mathrm{~cm}$. Byzantine Smalti, Millefiori, Gold Smalti, Ceramic tiles on border. Honeycomb panel, 2015. to Jesus, remains polarizing to the point where it has resurfaced as a popular subject in current debate. Biblical scholars and feminist historians alike are bringing to attention multiple narratives of Mary Magdalene that have been retold, restructured and redefined over the past two millennia, in order to render her story compatible with prevailing religious thought.

Throughout her mosaic corpus, Broca asks viewers to reappraise their preconceived notions about women and economic, political or spiritual power. With each series, Broca emerges with a new artistic style to underscore that, while all of her subjects are Biblical, she resists casting them into a specific "typology" of female hero. The female heroes' accounts cannot be used interchangeably to reaffirm familiar patterns of feminine behaviour (Vauchez 1983: 77; Weinstein - Bell 1982: 11). These women are not moral models of behaviour, but rather figures who are morally conflicted about their lives, choices and actions. In order to emphasize the diversity of each figure and their particular struggle Broca deliberately adopts divergent styles in each series to remind viewers of the psychological complexity imparted in each story Unlike in most Christian literature, there is no template, consistent framework or even essence of familiarity through which the artist tells these stories, nor even a moral lesson to be learned, especially among the female viewership gazing at Broca's work.
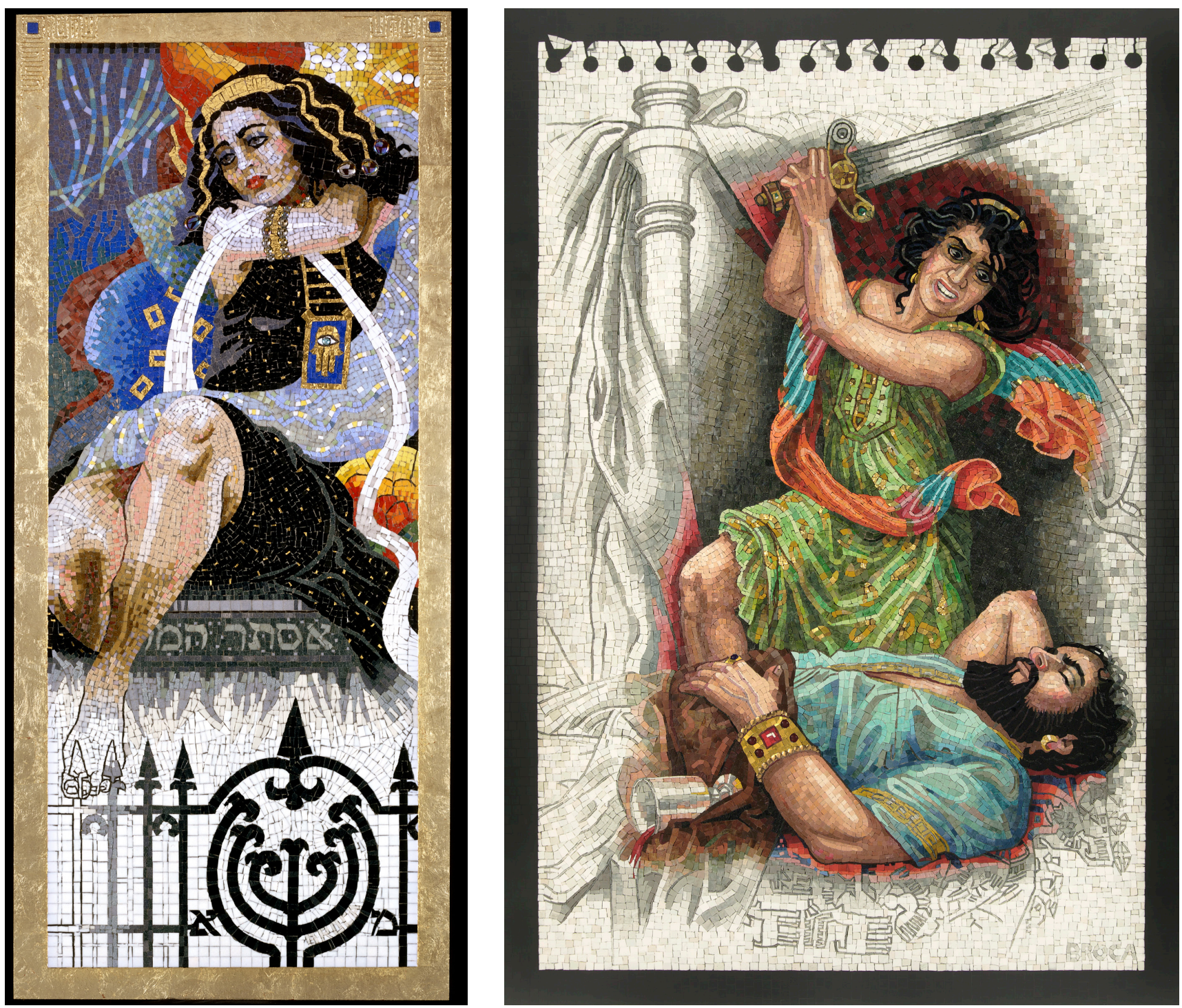


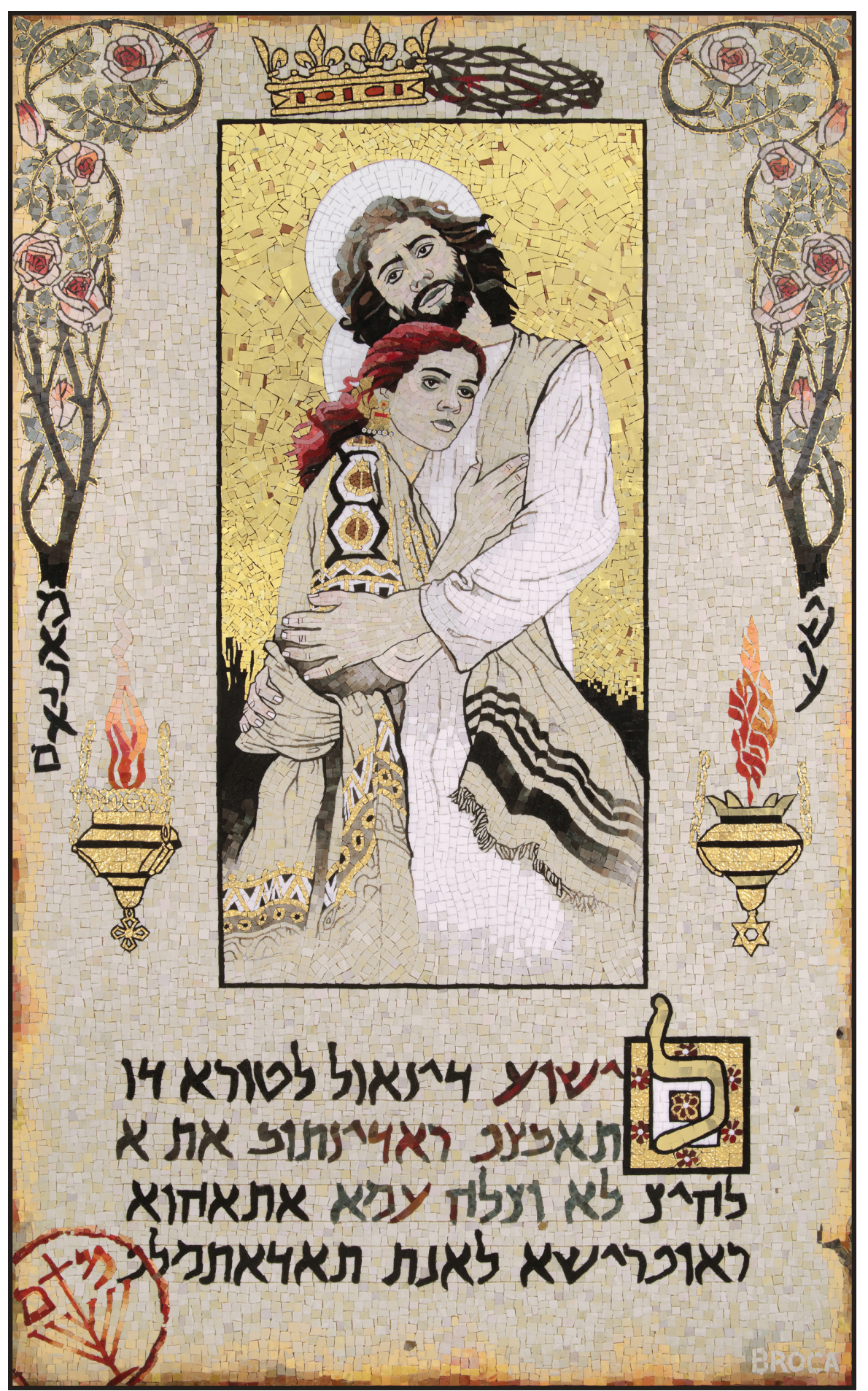

Broca designs her mosaics with an underlying motif carried throughout each specific series. These motifs remind viewers that each protagonist struggled with a unique set of circumstances. For Esther, they are the wrought iron gates confining her within the harem. For Judith, they are the perforated and torn page of the artist's sketchpad and the gradual concentration of colour toward the central figure in each mosaic. These express Broca's desire to vivify Judith through her sketchpad, giving her life, showing her as a real, feeling woman, not the abstract embodiment of the Jewish experience as her name, Judith, would indicate. Finally, Mary Magdalene is characterized by multilingual ancient script. Broca's message is that text brings Mary Magdalene to life. Mary Magdalene
Figure 13

Mary Magdalene The Sacred Union, 79 " x 48 " or 200 x $122 \mathrm{~cm}$, Byzantine Smalti, gold tesserae on honeycomb panel, 2019. 
can be understood not just through one tradition of the Bible but rather through many coexisting traditions.

\section{Finding a Voice, Speaking Truth to Power: The Book of Esther}

Broca's first mosaic series treated the figure of Esther. Completed in 2007, it is characterized by a blocky Byzantine style with a preponderance of azure, gold and lapis lazuli to mimic the wealth of the Persian Empire in which the eponymously named Book of Esther takes place.

The artist recounts the story of a woman who emerges from the confining and controlling barriers of palace life to enter the political realm, where she uses her own voice in service to her people, the Jews. A young orphan brought up by her cousin Mordechai, she is captured and sent with a large group of virgins to become an inmate within the harem of Ahasuerus, King of Persia. Once there, she is forced to participate in a beauty contest, with the winner emerging as the king's possession and new wife. Despite her reluctance to participate, Esther wins the contest and becomes queen.

Broca's mosaics depict the colourful but claustrophobic world of young women kept within a harem, wrought iron gates looming ever-present in the background. This enclosure becomes a metaphor for Esther's life, characterized by confinement and the restrictions upon Esther both as a woman and as a Jew. Esther knows from the example of her husband's first wife Vashti that if she defies his will, she will be banished. This is confirmed in accordance with Ahasuerus's decree that all wives in the kingdom of Persia are under the control of their husbands (Esther 1:22) $)^{5}$. The second restriction arises at the behest of Haman, the King's second-in-command, who obtains permission to initiate the slaughter of every Jew in the land. As a woman, and now as Ahasuerus's wife, if Esther refuses to submit to her husband's authority, she faces banishment; by revealing her identity as a Jew, she faces death according to Haman's decree. Esther defies three restrictions: she leaves the harem to enter Ahasuerus's throne

Figure 14

Queen Esther Seeking Permission to Speak, DIPTYCH, 64" x 88" Each panel 64" x 44" Smalti, Gems, Gold, Millefiori, Vitreous Glass on Honeycomb Panel, 2009.

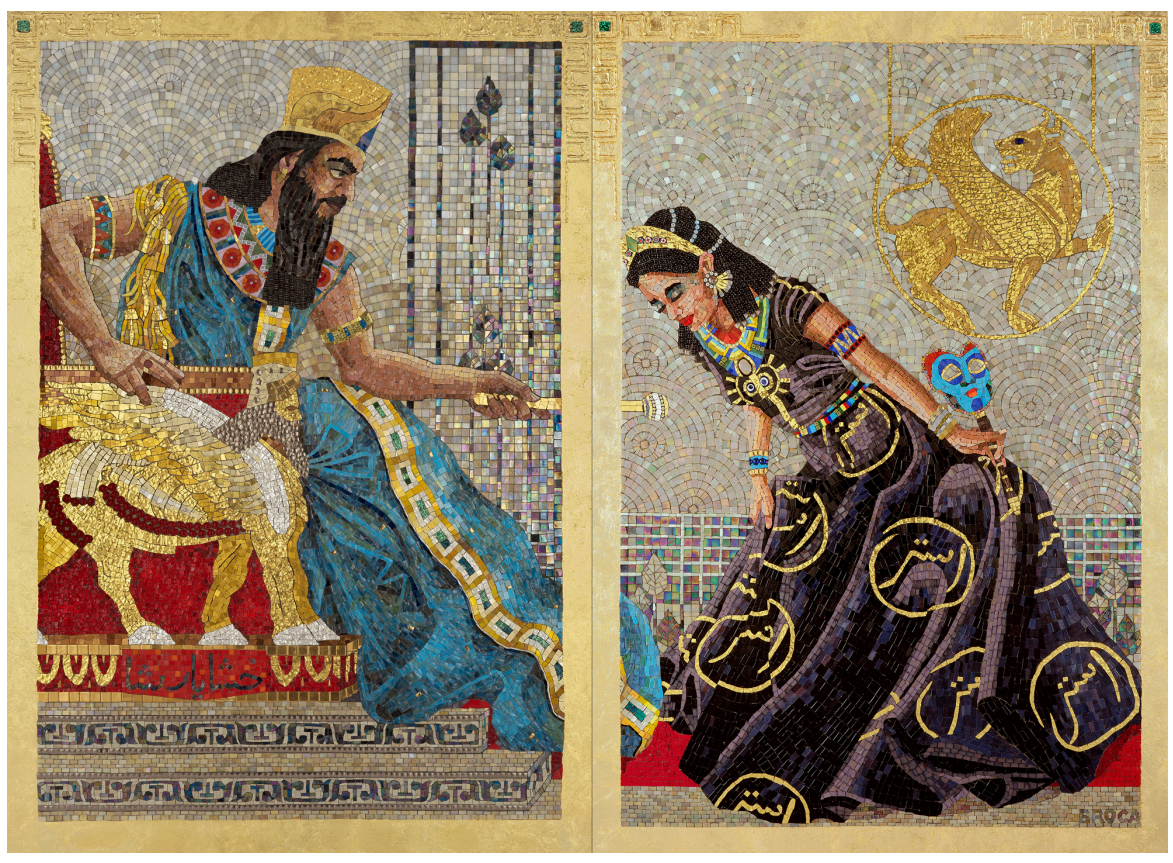

5 "[The King] sent letters to all the royal provinces, to every province in its own script and to every people in its own language, declaring that every man should be master in his own house." 
room $(7: 3)^{6}$, defies his legislation to silence wives $(1: 22)$ and reveals herself as a Jew $(7: 4)^{7}$. For these reasons, Broca entitles the series Esther: The Hidden and the Revealed (Broca et al. 2011).

The text does not explain how Esther has the capacity to influence and mobilize the king in a manner that his previous wife did not. It is clear, however, that she embodies the ancient notion of an auctoritas possessing the characteristics of a natural leader with personal and judicial authority, which does not surface until she faces a life-or-death situation. From this point on, Esther seems at home in the realm of power. The Biblical text states that she begins to make legislation, becoming the only woman in the Bible to legislate a religious observance (Esther $9: 32){ }^{8}$

\section{Judith: Entering the Battlefield}

In her second series, completed in 2015, Broca explores Judith as depicted in the Apocrypha. It was through her conversations with Dr. Adolpho Roitman, Curator of the Shrine of the Book (which houses the Dead Sea Scrolls) at the Israel Museum in Jerusalem, that Broca was introduced to Judith. Roitman suggested Judith as the perfect foil to Esther. Whereas Esther emerges quietly from the shadows, Judith is a woman of greater maturity, a widow alone in the world. Judith's story conveys the depth of human psychology, offering a glimpse into the life of a woman whose actions are motivated first by grief. She is transformed into a spiritual seeker, a suppliant looking for divine guidance. Once she enters Holofernes's camp, her actions are characterized by cunning and brute force. Her story ends in deep reflection and retreat. Judith is not naïve or inexperienced, as is Esther. Rather, her decisions are bold. She does not use Ester's gentle art of persuasion; her actions are swift, decisive and uncomfortable to herself, her maid and even to contemporary readers. Broca believes the viewer should experience this discomfort.

Judith lives in the town of Bethulia. Like Esther, her story is evocative of the challenges inherent in Jewish society and the struggle of their civilization: persecuted, marginalized and without voice. Her story begins amid a personal struggle as a childless grieving widow. Every aspect of the Judith story carries the watermark of the Jewish experience in antiquity; even her name signifies that she is a Jewish everywoman (Even 1992: 11). We learn of her existence in the second chapter of the Book of Judith when Bethulia faces annihilation as Holofernes, general of the Assyrian army, camps with his soldiers outside the town limits. Dressed in widow's weeds, Judith invites the town elders to her home to deliberate about the state of emergency. Finding the elders inactive, she silently prepares her own strategy to defeat Holofernes with the help of her maid. In the mosaics, Broca reminds viewers that this story of female heroism comes from both Jewish and Catholic canonical textual traditions. Ancient text is always the root and inspiration for Broca's visual journey. To emphasize its meaning, the artist creates the serrated edge of a torn page in each mosaic; present in each mosaic, this edge looms large as the unifying motif of the series, much like Esther's wrought iron enclosure.

6 "Then Queen Esther answered, 'If I have won your favour, O King, and if it pleases the king, let my life be given me - that is my petition — and the lives of my people — that is my request."

7 "For we have been sold, I and my people. To be destroyed, to be killed, and to be annihilated. If we have been sold merely as slaves, men and women, I would have held my peace but no enemy can compensate for this damage to the king."

8 "The command of Queen Esther fixed these practices of Purim, and it was recorded in writing." 
Figure 15

Judith Seducing Holofernes, DIPTYCH, 73 " x 96" or $185.5 \times 244 \mathrm{~cm}$. Each panel 73 " x 48" Byzantine Smalti, Millefiori, Gold Smalti, Ceramic tiles on border. Honeycomb panel, 2014
As Esther's story demonstrates a woman who effects political and religious change, Judith's offers a vision of a woman who is effective in the masculine military world. Judith formulates a plot to kill Holofernes before he can enter her village, lay siege to its infrastructure and take its people into slavery or murder them. Judith's plan for his assassination embodies fundamental characteristics of military strategy. She begins by eroding his defenses through his vulnerability to her in the face of inebriated sexual desire, which she successfully exploits (12:20). ${ }^{9}$ She effectively turns the female role in the military encampment on its head. In ancient stories such as the Iliad or plays such as Seven against Thebes (Aeschyl. Pers.: 333-5, 362-8) or The Trojan Women (Eur.Tro.: 203-204, 252-5, 310-416), women in military camps were servants and slaves sexually exploited as spoils of war (Rawlings 2007: 142). When Judith enters this masculine space, it is Holofernes who becomes helpless.

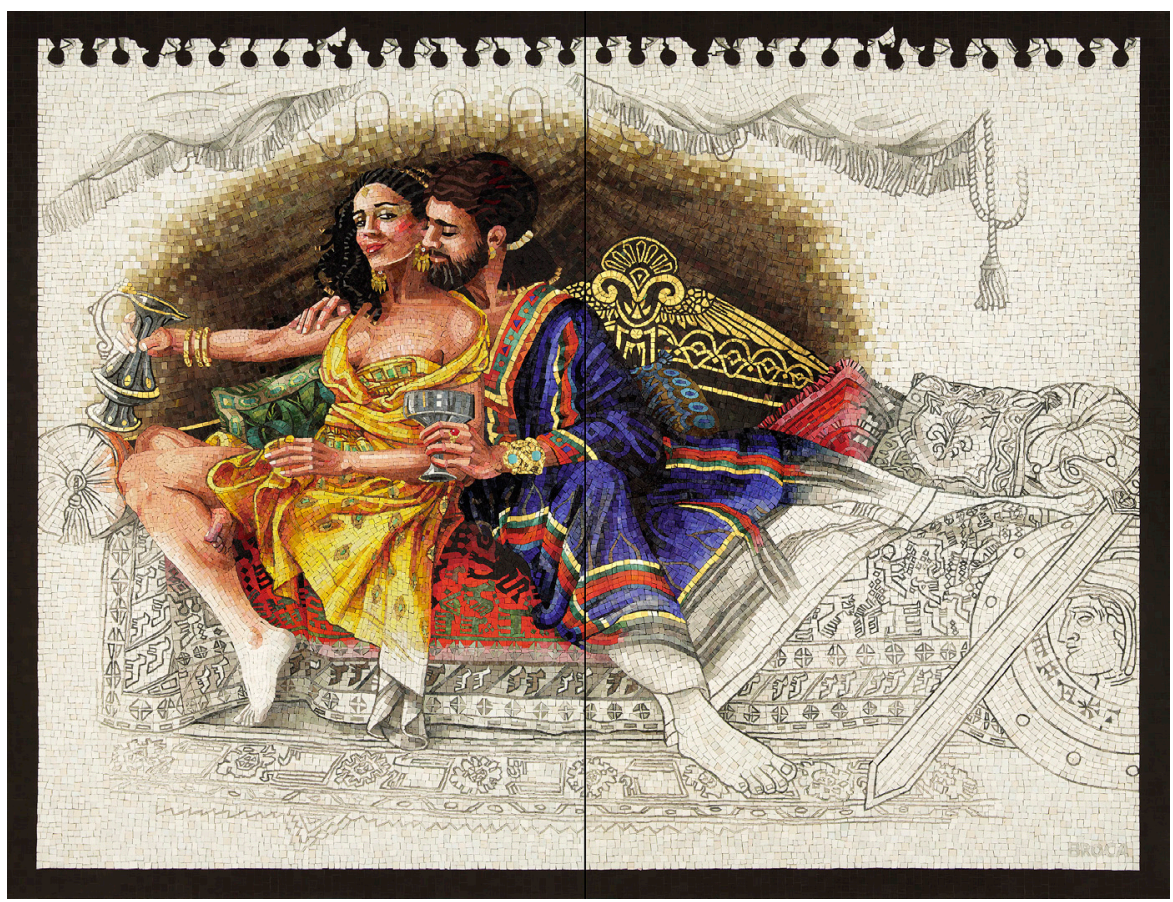

After Judith's victorious return to her town, details at the story's conclusion indicate that, like Esther, Judith has been transformed such that her role in society has entered the masculine realm of authority. While she has transgressed the acceptable bounds of feminine behaviour, she is allowed to retain her position. Esther changes religious law and continues to be effective in that position as the story concludes. The Judith story ends when she is accorded the respect of a military hero. This is shown through ritual: as is customary for military heroes, she is given the spoils of war, which she promptly donates to the temple in Jerusalem. She concludes her life as a sage advisor, military hero and town elder $(16: 21-24)^{10}$.

9 "And Holofernes took great delight in her and drank much more wine than he had drunk at any time in one day since he was born."

10 "After this time everyone returned to their own inheritance, and Judith went to Bethulia, and remained in her own possession, and she was in her time honourable in all the country. And many desired her, but none knew her all the days of her life, after that Manasses her husband was dead, and was gathered to his people. But she increased more and more in honour, and waxed old in her husband's house, being an hundred and five years old, and made her maid free; so she died in Bethulia; and they buried her in the cave of her husband Manassses." 
Mary Magdalene: Reading between and beneath the Lines of Palimpsests

In her two previous explorations of female heroism, Broca examines ancient texts to bring to light stories of women who were actively involved in the masculine realm. For her third and current series, her desire to explore the power dynamics in the Mary Magdalene story has proved far more complex. Mary Magdalene became known as a repentant prostitute in popular culture as a result of a confused interpretation of her story imparted in Homily 33 of Pope Gregory the Great (AD 540-604) (Gregory I 1844-1864: cols. 1238-1246, $33: 2)^{11}$. In fact, the Bible imparts that she is an apostle. She is, also, present at seminal moments in the life of Jesus as he suffers on the cross and as he rises again. Broca, however, broadens her historical lens to include a multitude of less well-known or understood texts that offer divergent perspectives on Mary Magdalene's import and her placement in the life of Jesus (Broca 2020a). By including numerous texts and their conflicting perspectives into her mosaic series, Broca depicts Mary Magdalene and her story as a palimpsest, or a text with erasures, lacunae, bringing to light vestiges of prior traditions. While the Bible has become Christianity's central canonical text, an examination of other textual traditions in a multitude of languages - Coptic, Greek, Latin and Amharic - reveal that additional insights into Mary Magdalene offer up vastly different notions about who she was and the nature of her relationship with Jesus. As Broca notes, the story of Mary Magdalene is a palimpsest (Broca 2020b). Reading her story, one discovers vestiges of past stories and re-imaginings, all buried deep under the surface. Broca uses the mosaic form to make these alternate perspectives open and available to contemporary discourse. To do so, she pairs text and mosaic in this series, reminding viewers that a substantial textual tradition supports multiple Mary Magdalene narratives. Many offer rich feminine spiritual components to traditional Church history.

In Broca's estimation, Mary Magdalene's character and relationship with Jesus exists on a spectrum with the canonical Biblical interpretation on one end and the Gnostic Gospels on the other. Gregory casts her as a fallen woman and a prostitute who serves as the foil to Jesus's mother, Mary, the silent, pristine and virginal woman who miraculously spawned him without being soiled by intercourse. On the other extreme is Mary of the eponymously names Gnostic Gospel of Mary Magdalene, depicted as the most beloved of Jesus and his rightful successor and potential wife. For Broca, whether Mary Magdalene truly was the "bride of Christ" is not entirely significant; despite its unclear nature, her impact on the Jesus story is undeniable (Raymond 2003: 105-107). Ultimately, the degree and nature of Mary Magdalene's relationship to Jesus impacts the very foundation on which his identity is based. Was he a sexual man? Was she his most beloved, as the Gospel According to Mary Magdalene asserts, and his favorite apostle? If her role has undergone systematic revision over the past millennium, as the texts Broca interprets suggest, then the necessity of such revisions is a testament to the power of this woman and her role in contemporary Christianity.

11 "She brought an alabaster vase full of perfume, and standing behind Jesus at her feet, she began to water them with her tears and to wipe them with the hair of her head; and they kissed them, and sprinkled them with perfume. 'It is very evident, my brethren, that this woman, formerly addicted to forbidden deeds, had used perfume to give her flesh a pleasant odor. What she had shamefully granted to herself, she now offered to God in a manner worthy of praise. She had desired the things of the earth by her eyes, but now mortifying them with penance, she was crying. She had emphasized the beauty of her hair to adorn her face, but she was now using it to wipe away her tears. His mouth had uttered words of pride, but now, kissing the feet of the Lord, she was staring at that mouth in the footsteps of her Redeemer ... She turned her crimes into so many virtues, that all that in her had despised God in sin was put to the service of God in penance." 
Figure 16

Painted Cartoon for Mary Magdalene Crossroads, 79" x 48" or $200 \times 122$ $\mathrm{cm}$, Byzantine Smalti, gold tesserae on honeycomb panel, (mosaic in progress).

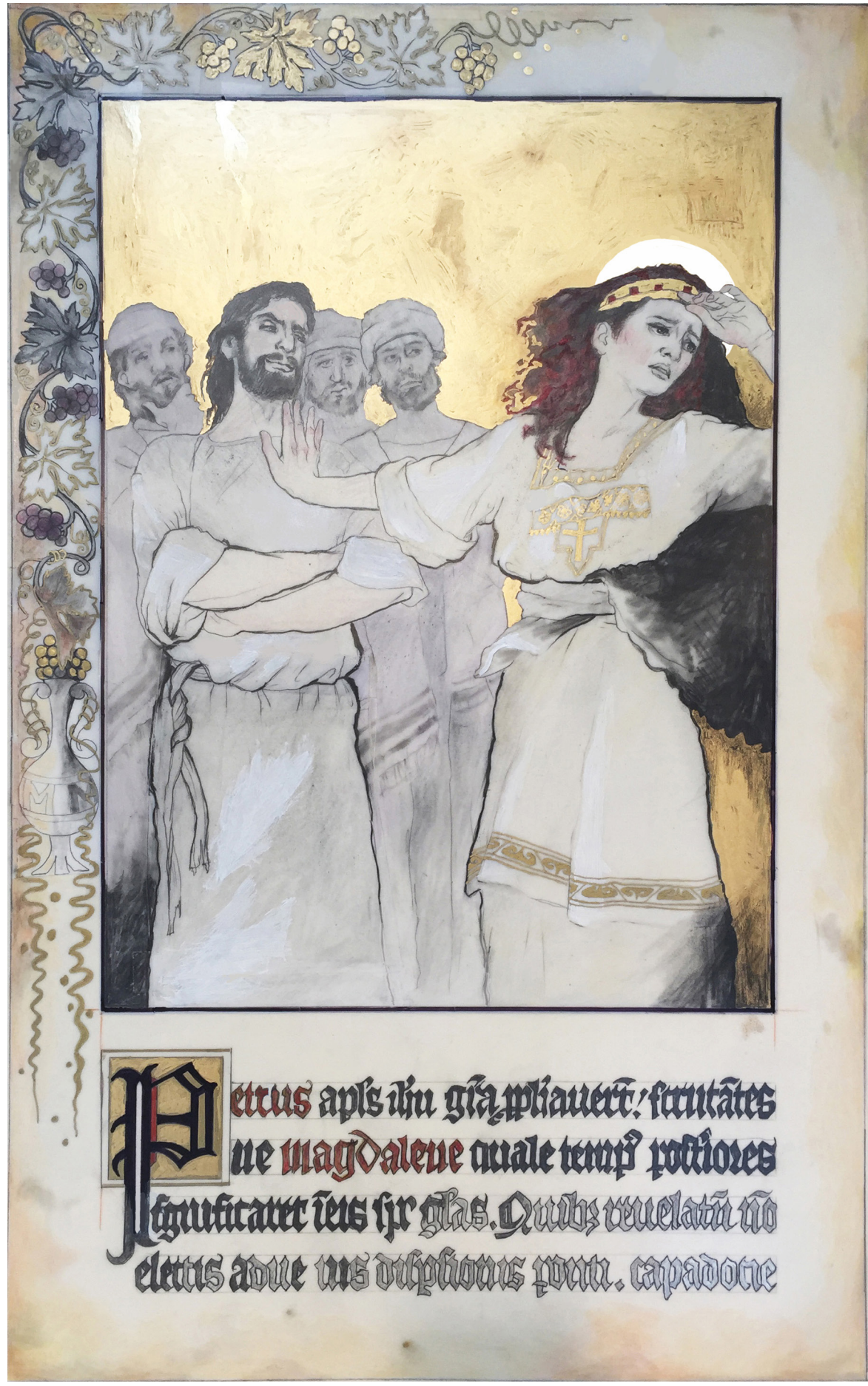

Illuminating these ancient texts on Mary Magdalene, Broca seems to draw back the curtain on the work of Pope Gregory as a theological simplifier. For example, Gregory advocates that the Marys in the Bible - the prostitute, the woman plagued by seven demons and the woman who anointed Christ, sister of newly risen Lazarus - were all one and the same (Gregory I 1844-1864: cols. 12381246, 33:2).Through these simplifications, not only did Gregory eliminate the necessity of prosopographal data on the Mary figures among unlettered Christian converts, but he also, by casting Mary into the role of prostitute, elevated the didactic appeal of Mary Magdalene and the mother of Jesus. The presence of a woman seeking redemption enhances the silence and pristine purity of Jesus's mother. In this regard, Gregory offers a clear message that women have two 
options of behaviour: be spotless and silent or repent (Gregory I 1844-64: cols. 1238-1246, 33:2).

The Gregorian version of Mary Magdalene, when compared to that of the Gnostic Gospels, reveals the refinement of a tradition. In the process, a once powerful woman recedes into the background. She is no longer a complex, fully integrated woman; rather she is transformed into another Eve, who seeks repentance, absolution and redemption. She is someone to be absolved by Jesus, lacking the moral fibre to be his successor (Luke 8:1-2).

\section{The Value of Women's Stories: Axiology and Postmodernism}

As artist and feminist, Broca asks how the female lived experience can be represented in a manner that gives respect and dignity to women's stories. Broca notes that many social and cultural variables, in flux throughout history, have greatly affected the way women's stories have been received (Broca 2020b). These values have impacted how and if these stories have been recorded at all. Factors in the instability in the perceived value of women's stories are the prevailing cultural and social climate, the motivation (currently referred to as the agenda) for telling the story, the identity of the artist recounting the story and the social esteem both the artist and the stories she depicts they are given. Finally, the physical placement of the artwork reveals much about its status, determining which audience will view it and the esteem its thematic content will receive. As historian Paul Veyne notes, these quantifiable axiological components determine and reflect the weight and cultural value that an artwork and its subject matter are accorded ${ }^{12}$. Historically, the opulent medium of mosaic has given value to the male experience; the female experience has not been recorded in a similar monumental way. Broca seeks to elevate and animate the female experience so that it receives the legitimacy given to the lives of legendary men in ancient history.

As a mosaic artist, Broca has studied masculine depictions in this genre. She reflects that the male experience is characterized by gravitas. Stories and legends are commemorated on a grand scale. A significant oral and written tradition often contributes to the mystique of the stories encoded in mosaic. Mosaics were also created at the request of wealthy and powerful men who wanted to merge their own identities with the famous figures in the works they commissioned. Furthermore, the gender of the patron greatly enhanced the perceived value of these mosaics. Broca notes that the gender of both the artist and patron remained a diagnostic factor in determining the social and cultural value of an art object and its relevance. These factors remained relevant until the 1970s.

In order to render the female experience equal in cultural value to that of the male, Broca extends to her female heroes an esteem and legitimacy that is equal to the representation of men in mosaic art. These include using ancient texts, rendering their stories in monumental scale and using handmade Venetian glass and often precious metals to illuminate her story. Also, ancient mosaics were commissioned for affluent homes and located in public buildings. To reach a similar demographic in contemporary culture, Broca brings her work into the public spaces of museums (Greenblatt 1991: 42-56) ${ }^{13}$. In this way, the stories of

12 Veyne (1984: 66), citing M. Weber, Essais sur la Théorie de la Science, J. Freund (trans.), Plon, 1967, 260-264.

13 Greenblatt argues that the presentation of an object not only reveals its perceived value but also succeeds in enhancing (or diminishing) this value in the eyes of viewers. 
ancient women can be celebrated, discussed and understood. It is to be hoped that they will become social reference points in both academic circles and in popular culture.
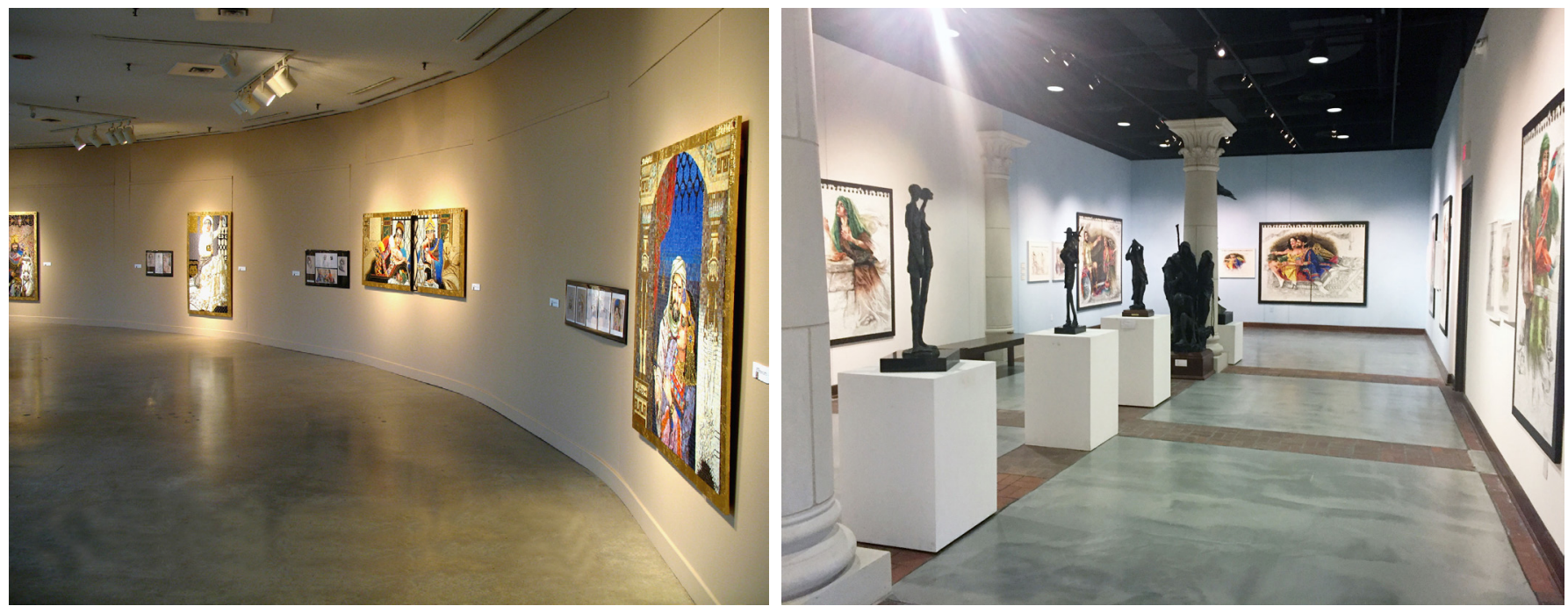

Figure 17

Queen Esther Exhibition at the JD Carrier Art Gallery Toronto, ON, 2006.

Figure 18

The Judith Mosaic Exhibition at The Museum of Biblical Art in Dallas, TX, 2016.

Figure 19

Completed Mary Magdalene mosaic panels in Broca's studio: Mary Magdalene Anointing, Mary Magdalene Sacred Union, 2019.

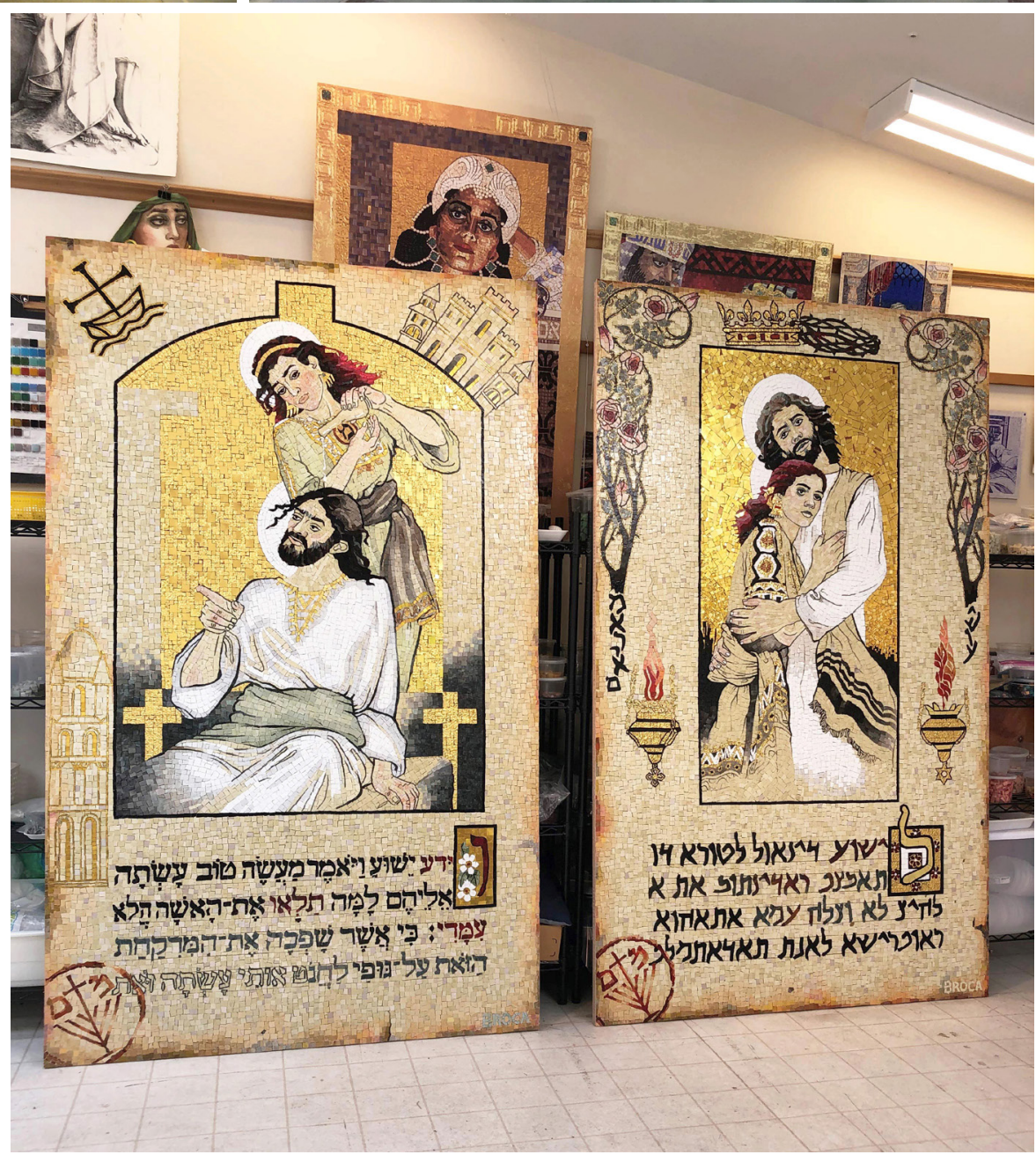

Although Broca employs the similar factors of medium, message and placement to lend her female heroes a gravitas akin to that of their ancient masculine counterparts, there is one aspect that she cannot replicate. While she feels that 
all mosaic artists should consider their historical responsibility when borrowing from the well of the vast art historical tradition of the figurative, she does not feel that the artist should be confined to a linear structure of time, when representing historic and legendary figures. For this reason, she looks to the concept of postmodern temporality to give her context to her stories (Fedosova 2015: 77). To insert her mosaic series in continuity with ancient tradition, which Broca deems necessary in order to redress history's sins of omissions, she overrides the rules and norms of time and its unbending progression to offer her female heroes the resonance and gravitas of history. Her mosaics interweave past, present and future, like a symbol of infinity rendering her heroines and their stories timeless; impervious to the passage of time and tide. In this way, she redresses history's wrongs by placing women and their stories as the central components in monumental art: a placement Broca feels should have been open to women's stories all along.

While Broca strives to formulate her own lexicon of female worthies with a tradition arising from antiquity, her renderings and interpretations of these women remain starkly contemporary. This is unavoidable since Broca herself is a female artist. This is an obvious testament of her modernity and separates her from the artists of antiquity (Edis-Barzman 1994: 327).

\section{Conclusion}

Lilian Broca uses the medium of mosaic as a monumental genre of art that documents stories of ancient heroes. She inserts the stories of three women recounted in Biblical texts to demonstrate that women, traditionally valued for virtue, beauty and devoted service to husbands and fathers, actually held powerful roles. These women and their stories must be celebrated for their transgression of the power boundaries upheld for their gender. Broca utilizes the monumental mosaic medium in a postmodern way to supersede the boundaries of linear time and rigid social norms. Time and age, reveals Broca, have always been applied to women in a pejorative way. Hence Broca offers her versions of how ancient stories could be represented if their focus were on prowess and intellectual acumen, rather than solely virtue. Broca hopes that we will see female authority not as a new development but one that, in the words of Ecclesiastes 3:15, has "already been, and [that] what will be has been before". 


\section{Bibliography - Kaynaklar}

Boccaccio 2001

Broca 2015

Broca 2020a

Broca 2020b

Broca et al. 2011

Clarke 2007

Cohen 2010

De Voragine - Grässe 1969

Domenici 1980

Doming 2012

Edis-Barzman 1994

Esther

Even 1992

Fedosova 2011

Greenblatt 1991

Gregory I 1844-1864

Judith

Luke

Rawlings 2007

Raymond 2003

Vauchez 1983

Veyne 1984

Warren 2018

Weinstein - Bell 1982

Wood 1996
G. Boccaccio, "Life of Dido", Famous Women (The I Tatti Renaissance Library), V. Brown (trans.), Harvard.

Lilian Broca Interview, 5 January

Lilian Broca, Interview, 15 February.

Lilian Broca, Interview, 3 March.

L. Broca - S. Campbell - Y. Wosk, with Judy Chicago (intro.), The Hidden and the Revealed: The Esther Mosaics of Lilian Broca, Gefen Publishing House.

A. Clarke, Prestige, Piety and Moral Perfection: Deruta Maiolica, the Social and Cultural Value of a Decorative Art, Unpublished Ph.D. Thesis, University of British Columbia.

A. Cohen, Art in the Era of Alexander the Great: Paradigms of Manhood and Cultural Traditions, Cambridge.

J. de Voragine - J. G. Th. Grässe, Legenda Aurea: Vulgo Historia Lombardia Dicta, Osnabrück.

G. Domenici, "Regola del Governo di Cura Familiare", C. Gilbert (ed.), Italian Art 1400-1500: Sources and Documents, Prentice Hall, 144-145.

K. Doming, Girl Power in Late Antiquity: Coronation of the Winner Floor Mosaic of the Villa Romana del Casale, Unpublished, University of Amsterdam.

K. Edis-Barzman, "Beyond the Canon: Feminists Postmodernism and the History of Art", The Journal of Aesthetics and Art Criticism 52, 327-339.

Book of Esther, The New Oxford Annotated Bible, New Revised Standard Edition, M. Coogan (ed.), 2010.

Y. Even, "Mantegna's Uffizi Judith: The Masculinization of a Female Hero", Kosthistorisk Tidskrift 61, $8-20$.

T. Fedosova, "Reflection of Time in Postmodern Literature", Athens Journal of Philology 2, 2, 77-88.

S. Greenblatt, "Resonance and Wonder", Exhibiting Cultures: The Poetics and Politics of Museum Display, 42-56 Smithsonian Institution.

Gregory I, Homiliarum in Evangelia, Lib. II, Patrologia Latina 76, J.-P. Migne, cols. 1238-1246.

Book of Judith, The New Oxford Annotated Bible, New Revised Standard Edition, Michael Coogan (ed.), 2010.

Book of Luke, The New Oxford Annotated Bible, New Revised Standard Edition, M. Coogan (ed.), 2010.

L. Rawlings, The Ancient Greeks at War, Manchester and New York.

Blessed Raymond of Capua, The Life of St. Catherine of Siena, George Lamb (trans.), TAN Books.

A. Vauchez, The Laity in the Middle Ages: Religious Beliefs and Devotional Practices, D. Bornstein (ed.), M. Schneider (trans.), University of Notre Dame.

P. Veyne, Writing History: Essay on Epistemology, M. Moore-Rinvolucri (trans.), Plon 1967.

L. Warren, Reading Plutarch's Women: Moral Judgement in the Moralia and Some Lives, Unpublished Paper, Stellenbosch University.

D. Weinstein - R. Bell, Saints and Society, Chicago.

J. Wood, Women, Art and Spirituality: The Poor Clares in Early Modern Italy, Cambridge. 
